\title{
Pesticide and Nutrient Loads of Lake Bosomtwe in the Ashanti Region of Ghana
}

\author{
Collins Kuffour1, David Kofi Essumang2, Hugh Komla Akotoye ${ }^{3}$, \\ Richard Amankwah Kuffour ${ }^{1}$, Janice Dwomoh Abraham ${ }^{4}$
}

\author{
${ }^{1}$ Department of Environmental Health and Sanitation Education, Akenten Appiah-Menka University of Skills Training and \\ Entrepreneurial Development, Mampong, Ashanti Region, Ghana \\ ${ }^{2}$ School of Physical Sciences, University of Cape Coast, Cape Coast, Central Region, Ghana \\ ${ }^{3}$ Department of Environmental Science, University of Cape Coast, Cape Coast, Central Region, Ghana \\ ${ }^{4}$ Department of Biological Sciences Education, Akenten Appiah-Menka University of Skills Training and Entrepreneurial \\ Development, Mampong, Ashanti Region, Ghana \\ Email: ckuffour@uew.edu.gh
}

How to cite this paper: Kuffour, C., Essumang, D.K., Akotoye, H.K., Kuffour, R.A. and Abraham, J.D. (2021) Pesticide and Nutrient Loads of Lake Bosomtwe in the Ashanti Region of Ghana. Journal of Water Resource and Protection, 13, 794-806. https://doi.org/10.4236/jwarp.2021.1310042

Received: August 20, 2021

Accepted: October 15, 2021

Published: October 18, 2021

Copyright $\odot 2021$ by author(s) and Scientific Research Publishing Inc. This work is licensed under the Creative Commons Attribution International License (CC BY 4.0)

http://creativecommons.org/licenses/by/4.0/

(c) (i) Open Access

\begin{abstract}
Pollution of Lake Bosomtwe is a major concern in Ghana due to its derived socio-economic benefits such as employment, ecotourism and major protein source to the people in the basin. Besides these benefits, the lake water is used for domestic purposes and has since served as the drinking water source to the people. However, the use of agrochemicals within the basin has intensified within the last decade. The problems associated with fertilizer and pesticide use in the Bosomtwe basin seem to carry with it a higher price, which, if not identified and checked, will overshadow the desired benefits of the lake. This study assesses pesticide and nutrient loads of Lake Bosomtwe in the Ashanti Region of Ghana. Fifty-four (54) lake water samples were collected from September 2016 to February 2017. Pesticide samples were extracted using the solid phase extraction method and GCMS to identify the pesticides present in the water samples and determine their loads. The data obtained were analyzed using Statistical Product Service Solutions (SPSS version 20) for descriptive statistics. The concentration of dichlorvos was a bit lower when compared with the WHO/USEPA guidelines of $5 \mathrm{ppb}$ for surface water. Diazinon had a mean concentration of $0.28 \pm 0.03 \mathrm{ppb}$ which was higher than the WHO $0.05 \mathrm{ppb}$ and USEPA $0.04 \mathrm{ppb}$ for surface water bodies. The detection of diazinon confirms the findings from the field survey, which revealed that diazinon, is an active ingredient of a pesticide with a trade name "Akate suro", which was extensively used by cocoa farmers along the banks of the lake. The mean concentration recorded for nitrate and phosphate were $0.15 \pm 0.05 \mathrm{mg} / \mathrm{L}$ and $0.40 \pm 0.12 \mathrm{mg} / \mathrm{L}$ respectively. The pesticides application inventory and implications of pesticide and nutrient loads on the lake are discussed in the paper.
\end{abstract}




\section{Keywords}

Organochlorine, Organophosphorus, Pesticide, Fertilizer, Bosomtwe

\section{Introduction}

Lakes are vulnerable, and their overall condition is deteriorating globally [1]. Pollution of Lake Bosomtwe is a major concern in Ghana due to its derived socio-economic benefits. "Reference [2] enumerated employment, ecotourism and major protein source as some of such benefits." Besides these benefits, the lake water is used for domestic purposes and has since served as the drinking water source to the people in the basin. However, the use of agrochemicals within the Lake Bosomtwe basin has been intensified within the last decade [3]. The agrochemicals have brought increased productivity and other benefits in terms of food security [4]. On the other hand, exposure to residues of the agrochemicals may affect the environment and human health through different emission routes [5]. The problems associated with fertilizer and pesticide use in the Lake Bosomtwe basin seem to carry with it a higher price, which, if not identified and checked, will overshadow the desired benefits [6] [7]. Pesticide and fertilizer residues carried into the lake water may potentially impair the quality of the lake water [8]. Mostly, the quality of the lake water in terms of its physico-chemical properties is often assessed to the exclusion of pesticides. This study was to assess pesticide and nutrient loads of the Lake Bosomtwe in the Ashanti Region of Ghana.

\section{Materials and Methods}

\subsection{Study Area}

The study was conducted in three communities that engaged in extensive farming along the banks of Lake Bosomtwe as shown in Figure 1. The Lake is located in the Bosomtwe-Atwima-Kwawoma District of the Ashanti Region of Ghana. The District lies within latitude $6^{\circ} 43^{\prime}$ North and longitude $1^{\circ} 46^{\prime}$ West.

The Lake Bosomtwe area is located within the equatorial zone with a rainfall regime typical of the moist semi-deciduous forest zone of Ghana [9]. The lake almost covers all the flat-leveled low lands between the high lands of the Bosomtwe basin and the remaining little flat-leveled low lands of the basin are used by local inhabitants to carry out subsistence agriculture. Most of the farmers are also involved in other cash crop farming such as cocoa, oil palm and citrus plantations which are done on a relatively small scale [9].

\subsection{Research Design}

Field and laboratory techniques were used in this study. Purposive sampling technique was used to sample water from the selected communities for laboratory analysis. Fifty-four (54) lake water samples were collected from September, 


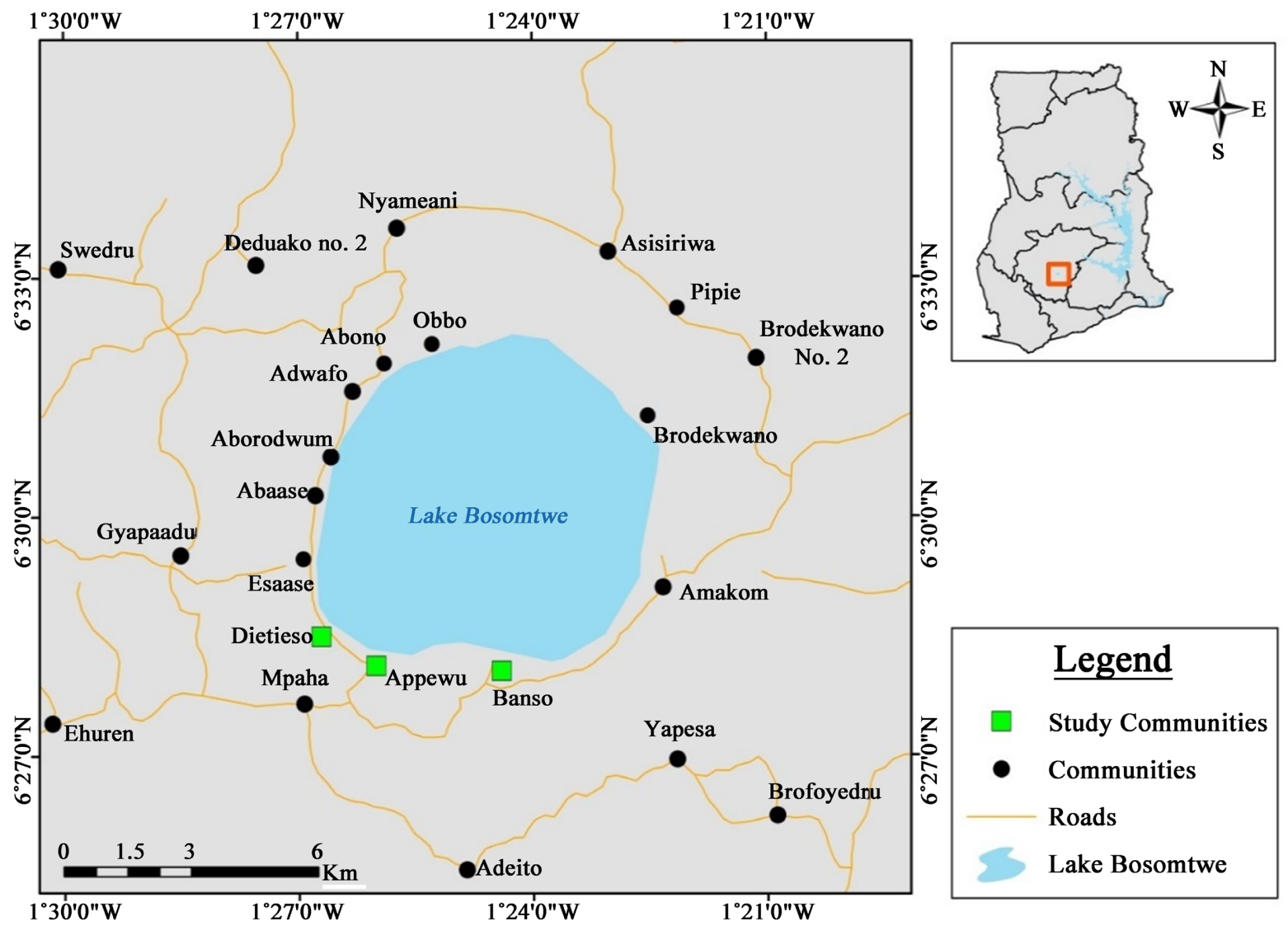

Figure 1. A map of the lake area showing sampling sites.

2016 to February 2017 to the laboratory for analysis of pesticides and nutrient loads. Samples were analyzed using the procedures prescribed by American Public Health Association [10] with minor modifications. A structured questionnaire was used to assess the level of use of pesticides and fertilizers by inhabitants within the Bosomtwe basin. Using discriminative snowball which is also non-probability sampling technique, sixty (60) respondents, twenty (20) from each community were selected for interview to take inventory of pesticides and fertilizers application in the basin.

\subsection{Solid Phase Extraction and Elution of Pesticides}

The water samples were filtered by passing each sample through a filter paper. A volume of $500 \mathrm{~mL}$ of each sample was extracted at room temperature using solid phase extraction method. A weak anion exchange solid extraction octadecyl $\mathrm{C}_{18}$ cartridges were preconditioned with $5 \mathrm{~mL}$ of $0.1 \% \mathrm{NH}_{4} \mathrm{OH}$ in methanol followed by double distilled water. Water samples were passed through $\mathrm{C}_{18}$ column cartridges through polypropylene tubing under vacuum at a high flow rate $(10 \mathrm{~mL}$ per minute). A volume of $2 \mathrm{~mL}$ of methanol was used to elute the uncategorized organic compounds into a sample valve. Each extract was then dried using $\mathrm{Na}_{2} \mathrm{SO}_{4}$. Extracted samples were fortified with $20 \mu \mathrm{L}$ of the $200 \mu \mathrm{g} / \mathrm{L}$ of mixed internal standards. The spiked extracts were subjected to nitrogen evaporation 
until the final volume required for analysis was obtained. The samples were analyzed using Gas Chromatograph Mass Spectrometer

\section{Quantification and Limit of Detection of Pesticide}

The residue levels of the pesticides were quantitatively determined by the external standard method using peak area. Measurement was carried out within the linear range of the detector following the procedures described by [11] [12]. The peak areas whose retention times coincided with the standards were extrapolated on their corresponding calibration curves to obtain the concentration. The limit of detection of the pesticides determined was based on the extract of the fortified samples that were serially diluted by a factor of two to give different concentrations. One out of each concentration that gave a response three times the standard deviation of the least fortified sample was noted

\subsection{Quality Assurance}

Linearity was evaluated in the $15-150 \mu \mathrm{g} / \mathrm{L}$ concentration range. Four standard concentrations $(15,30,75$ and $150 \mu \mathrm{g} / \mathrm{L})$ were prepared and used to construct a calibration curve to check the linearity of the instrument response and also for quantification. The regression coefficients $\left(\mathrm{R}^{2}\right)$ of the calibration curve were calculated by plotting area ratio against concentration. For most of the targeted compounds, regression coefficient was 0.99 indicating good linearity. Four blank samples were analyzed and the average concentrations of each analyte in the blanks were used to correct the concentration of the corresponding analyte in the test samples. Recovery test was conducted by spiking a mixture of native standards $(150 \mu \mathrm{g} / \mathrm{L})$ into deionized water and then extracted following the same procedures used for the real samples. The reproducibility of the method was then determined. The obtained recoveries and RSD values were largely satisfactory, indicating a fairly good precision for most of the analytes. The limit of detection (LOD) (i.e., concentration that yielded signal to noise ratio of $\geq 3$ ) and limit of quantification (LOQ) (i.e., concentration that yielded signal to noise ratio of $\geq 10$ ) for the various analytes were determined for each sample and the median LOD and LOQ values were reported as the threshold values for each analyte.

\section{Nutrient Loads of the Lake Water}

Phosphate and Nitrate were the main nutrients whose loads were determined following the standard procedures prescribed by reference [10].

\subsection{Data Analysis}

The data obtained were analyzed using Statistical Product Service Solutions (SPSS version 20) for descriptive statistics and the results were presented as shown below.

\section{Results and Discussion}

\subsection{Organophosphate Pesticides}

Table 1 shows the mean concentrations of pesticide loads of Lake Bosomtwe. 
Table 1. Mean pesticide loads of the lake water in ( $\mathrm{ppb})$.

\begin{tabular}{|c|c|c|c|c|c|}
\hline Pesticides & Conc. (ppb) & Skewness & Kurtosis & Minimum & Maximum \\
\hline \multicolumn{6}{|l|}{ Organophosphorus } \\
\hline Dichlorvos & $0.11 \pm 0.09$ & 0.31 & 0.72 & 0.03 & 0.18 \\
\hline Diazinon & $0.28 \pm 0.03$ & -0.14 & -1.06 & 0.12 & 0.44 \\
\hline Chlorpyrifos & $0.16 \pm 0.05$ & 0.58 & 0.67 & 0.08 & 0.28 \\
\hline methyl-chlorpyrifos & $0.19 \pm 0.05$ & -0.59 & -0.73 & 0.09 & 0.26 \\
\hline Triphenyl phosphate (TPhP) & $0.16 \pm 0.06$ & 0.24 & 0.61 & 0.06 & 0.31 \\
\hline Coumaphos & $0.10 \pm 0.05$ & 0.44 & -0.16 & 0.01 & 0.21 \\
\hline \multicolumn{6}{|l|}{ Organochlorines } \\
\hline Lindane & $0.22 \pm 0.04$ & 4.05 & 16.85 & 0.04 & 1.81 \\
\hline Dichlorobenzophenone & $0.05 \pm 0.02$ & 1.43 & 3.72 & 0.02 & 0.13 \\
\hline Heptachlorepoxide & $0.11 \pm 0.03$ & 0.24 & -0.58 & 0.05 & 0.19 \\
\hline$\gamma$ chlordane & $0.27 \pm 0.10$ & 0.93 & 0.08 & 0.08 & 0.65 \\
\hline a chlordane & $0.12 \pm 0.05$ & 0.53 & 0.46 & 0.03 & 0.24 \\
\hline Dieldrin & $0.04 \pm 0.02$ & 1.07 & 1.23 & 0.01 & 0.09 \\
\hline $\begin{array}{l}\text { Dichlorodiphenyldichloroethylene } \\
\text { (DDE) }\end{array}$ & $0.12 \pm 0.07$ & 0.92 & 1.63 & 0.01 & 0.31 \\
\hline Endoslfan Sulphate & $0.15 \pm 0.06$ & 0.11 & -0.80 & 0.05 & 0.27 \\
\hline \multicolumn{6}{|l|}{ Synthetic pyrethroids } \\
\hline Permetrin & $0.48 \pm 0.30$ & 1.32 & 1.45 & 0.10 & 1.32 \\
\hline \multicolumn{6}{|l|}{ Phenol group } \\
\hline$\sigma$ phenylphenol & $0.05 \pm 0.05$ & 0.84 & -0.349 & 0.00 & 0.1714 \\
\hline
\end{tabular}

Source: field data, 2017.

Dichlorvos recorded a mean concentration of $0.11 \pm 0.09 \mathrm{ppb}$ with minimum and maximum concentrations of $0.03 \mathrm{ppb}$ and $0.18 \mathrm{ppb}$ respectively. The concentration of dichlorvos was a bit lower when compared with the WHO/USEPA guidelines of $5 \mathrm{ppb}$ for surface water. "Reference [13] attributed movement of contaminants into the lake Bosomtwe to farming activities occurring in the basin." According to [14], the toxicity of dichlorvos for freshwater and estuarine fish is moderate to high, and it does not bioaccumulate in fish. However, dichlorvos has the potential to induce altered immune response in fish [15].

Diazinon had a mean concentration of $0.28 \pm 0.03 \mathrm{ppb}$ during the study. "Reference [16] recorded lower concentration $(0.03 \mathrm{ppb})$ of this same pesticide for surface waters in Dormaa West in Brong Ahafo Region of Ghana." The mean concentration of diazinon was higher than the WHO $0.05 \mathrm{ppb}$ and USEPA 0.04 $\mathrm{ppb}$ for surface water bodies. The detection of diazinon confirms the findings from the field survey, which revealed that diazinon, is an active ingredient of a pesticide with a trade name "Akate suro", which is extensively used by cocoa farmers along the banks of the lake. Diazinon has been found to capably cause 
acute and chronic intoxication [17].

Chlorpyrifos and Methyl-Chlorpyrifos respectively had mean concentrations $0.16 \pm 0.05 \mathrm{ppb}$ and $0.19 \pm 0.05 \mathrm{ppb}$. The mean concentrations of both chlorpyrifos and methyl-chlorpyrifos were higher when compared with the $0.08 \mathrm{ppb}$ limit prescribed by the USEPA. Chlorpyrifos like other organophosphate insecticides acts on the nervous system of the parasites and other organisms such as fish, birds and mammals that come in contact with these pesticides. It inhibits acetylcholinesterase an enzyme that hydrolyses acetylcholine.

$\mathrm{TPhP}$ and Coumaphos respectively had mean concentrations of $0.16 \pm 0.06$ ppb and $0.10 \pm 0.05 \mathrm{ppb}$. Coumaphos, TPhP and other organophosphate pesticides have been extensively reported by [6] in Fosu lagoon, Chemu lagoon, Korle lagoon all in Ghana. Coumaphos has been linked to cause so many disturbances in aquatic systems particularly lakes [18]. An increasing number of studies linked exposure to $\mathrm{TPhP}$ with reproductive and developmental toxicity, neurotoxicity, metabolic disruption, endocrine effects, and genotoxicity. TPhP has also been found to induce significant estrogenic activity. Organophosphates have been identified to be a contributing factor of eutrophication in water bodies particularly lakes [19].

\subsection{Organochlorine Pesticides (OC's)}

Eight (8) problematic class of organochlorine pesticide residues were detected in the samples as shown in Table 1. They include Lindane Dichlorobenzophenone, Heptachlorepoxide, Gamma chlordane, Alpha chlordane, Dieldrin, DDE and Endoslfan sulphate. It was observed from the analysis of the questionnaire that most of the organochlorine pesticides detected in the lake water were not actively used in the basin anymore but their concentration still persists. This could be in line with the assertion of [6] that OC's are resistant to microbial and photolytic degradation, and are therefore persistent in the environment (soils and water) where they are applied. Similar concentrations of OC's have been reported by [6] for Fosu, Korle and Chemu lagoons in Ghana.

Exposure to concentrations of organochlorine pesticides over a long period may eventually lead to a substantial body burden of toxic chemicals. Acute ingestion of aquatic products contaminated with organochlorine pesticides may cause a loss of sensation around the mouth; hypersensitivity to light, sound, and touch; dizziness, tremors, nausea, vomiting, nervousness, and confusion [20]. Population-based studies have revealed possible relations between the exposure to organochlorine pesticides and serious health effects including cardiovascular diseases, negative effects on the male reproductive system and on the nervous system, dementia, and also a possible increased risk for non-Hodgkin's lymphoma [21].

\subsection{Synthetic Pyrethroids}

Permetrin was the only pesticide identified under this group and a phenol type 
pesticide, $\sigma$-phenylphenol as shown in Table 1 . The mean concentration recorded for Permetrin and $\sigma$-phenylphenol were $0.48 \pm 0.30 \mathrm{ppb}$ and $0.05 \pm 0.05$ ppb respectively. "Reference [16] reported similar concentration for surface water bodies in Dormaa West." The mean concentration of Permetrin observed at the various sampled sites with detectable residues was found to be higher than the World Health Organization (WHO) Maximum Residue Limit of $0.05 \mathrm{ppb}$ for Permetrin. It is reported that, exposure to synthetic pyrethroids can cause hyperexcitation, aggressiveness, incoordination, whole-body tremors, and seizures [16].

\subsection{Nitrate}

The nitrate levels recorded during the study ranged from $0.01 \mathrm{mg} / \mathrm{L}$ to $0.25 \mathrm{mg} / \mathrm{L}$ with a mean value of $0.15 \pm 0.05 \mathrm{mg} / \mathrm{L}$ as shown in Table 2 . The mean nitrate value recorded for the study was a bit lower when compared with the overall mean nitrate concentration of $1.3 \mathrm{mg} / \mathrm{L}$ recorded by [13] for Lake Bosomtwe. However, the concentration observed for this study $(0.16 \mathrm{mg} / \mathrm{L})$ by far fell in line with the nitrate levels obtained by [22] in Lake Volta $(0.2-1.70 \mathrm{mg} / \mathrm{L})$ and elsewhere in Nigeria $(0.10-2.60 \mathrm{mg} / \mathrm{L})$ by [23]. The level of nitrate in the lake was far below the W.H.O limit of $10 \mathrm{mg} / \mathrm{L}$. Nitrate levels exceeding $5 \mathrm{mg} / \mathrm{L}$ in most cases are indicative of anthropogenic pollution which could be harmful to aquatic organisms and humans. The level of nitrate in the Bosomtwe could be attributed to the use of nitrogenous fertilizers along the bank of the lake by most farmers. "Reference [13] attributed nitrate levels in surface water to increase in surface runoff, bare areas and leaching of nitrogenous fertilizers from nearby farmlands." A study by [24] concluded that, nitrogen fertilizer application contributed to an increase in nitrate levels in surface water through surface run-off. Fertilizers on farmlands could be sub-lethal to native fish species and other aquatic organisms [25].

\subsection{Phosphate}

The phosphate level ranged between $0.098 \mathrm{mg} / \mathrm{L}$ to $0.68 \mathrm{mg} / \mathrm{L}$ with a mean concentration of $0.40 \pm 0.12 \mathrm{mg} / \mathrm{L}$ as shown in Table 2 . The mean concentration of phosphate had marginally increased when compared with the mean values of $0.40 \mathrm{mg} / \mathrm{L}$ recorded by [13] in the same lake. The mean phosphate concentration for this study was slightly higher when compared with the values $(0.031 \mathrm{mg} / \mathrm{L})$ recorded by [26] in the same lake. In view of this, lake can be said to be polluted considering the fact that the minimum phosphate level for most uncontaminated lakes ranges from $0.01-0.03 \mathrm{mg} / \mathrm{L}$ [27]. The level of phosphate in the lake water

Table 2. Nutrient Load of the Lake Water.

\begin{tabular}{|c|c|c|c|c|c|c|c|c|c|}
\hline & Sept & Oct & Nov & Dec & Jan & Feb & G. mean & $\min$ & $\operatorname{Max}$ \\
\hline $\mathrm{NO}^{3-}(\mathrm{mg} / \mathrm{L})$ & $0.13 \pm 0.06$ & $0.10 \pm 0.03$ & $0.21 \pm 0.03$ & $0.17 \pm 0.04$ & $0.13 \pm 0.06$ & $0.171 \pm 0.03$ & $0.15 \pm 0.05$ & 0.011 & 0.250 \\
\hline $\mathrm{PO}^{4-}(\mathrm{mg} / \mathrm{L})$ & $0.40 \pm 0.13$ & $0.33 \pm 0.17$ & $0.47 \pm 0.08$ & $0.38 \pm 0.06$ & $0.46 \pm 0.13$ & $0.35 \pm 0.05$ & $0.40 \pm 0.12$ & 0.098 & 0.680 \\
\hline
\end{tabular}

Source: field data, 2017. 
may be attributed to high activities such as rapid evaporation and mineralization of decomposed material in the water [23] [28]. More so, the gradual increase in phosphate concentration in the lake water may be also attributed to the use of phosphate fertilizers, detergents and waste from domesticated animals around the lake. This is an indication of anthropogenic pollution [29]. "Reference [30] reported that high values of phosphate support algae growth and may affect the fish in the lake water."

\subsection{Pesticide and Fertilizer Application Inventory}

\subsubsection{Background Information about Farmers}

The study revealed that majority of the respondents about $34 \%$ had no formal education and $43 \%$, had basic education as shown in Figure 2. "Reference [13] enunciated that, the low level of education of the people in the Bosomtwe basin could also be an indicator of poor or misapplication of agrochemicals on farms." Misapplication of agrochemicals enhances movement of chemicals into water bodies causing a whole lot biological and chemical disturbances [31].

Furthermore, most of the farmers within the Bosomtwe basin were low income earners. $90 \%$ of the respondents earned between 100-300 Ghana Cedis within a month as shown in Figure 3. In view of this, there may be over dependence on the few resources available while the inhabitants quest to get means of subsistence. Often the problems of income earned and the environment are intertwined

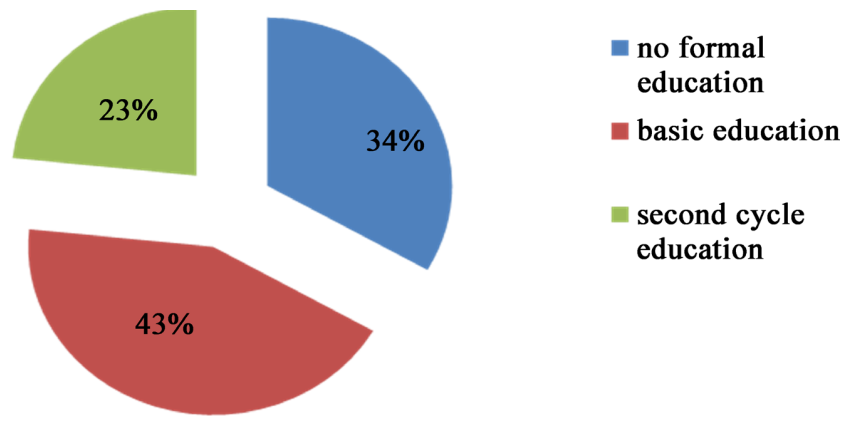

Figure 2. Split pie chart showing educational levels of farmers.

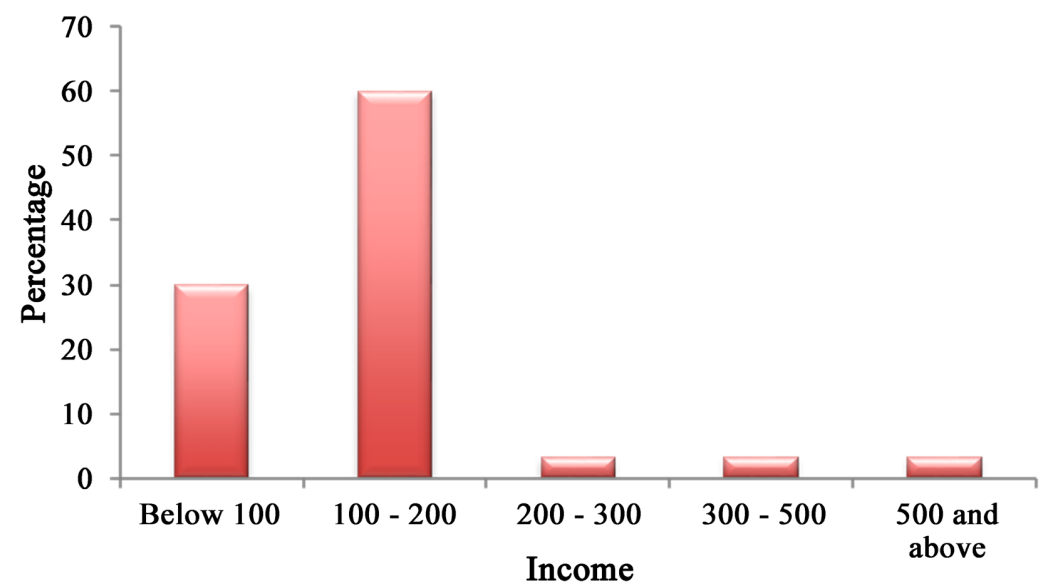

Figure 3. Bar chart showing income levels of farmers. 
and poverty varies proportionally to environmental degradation [32]. The World Bank maintains a notion that the poor do not willfully degrade the environment but poor communities often lack the resources to avoid degrading their environment [32]. The inhabitants within such communities therefore adopt poor low technological and ecologically threatening land use practices which significantly affects the lake water quality [33] [34].

\subsubsection{Farmers' Knowledge of Pesticide}

"Reference [35] posited that the manners in which pesticide products are used are likely to be driven by the extent of knowledge an individual has on the product." Pesticide labels though are contained in features that are known or easily comprehended and not too abstract to users [36], it was however revealed that $60 \%$ of the farmers were unable to read the manufacturer's instruction while $40 \%$ were able to read manufacturer's instructions. Meanwhile $53 \%$ of the total respondents that could read manufacturers instruction did not respect manufacturer's instruction. This may give satisfactory reasons for farmers' poor knowledge of the risks associated with the use of pesticides, including the essential role of the correct application and the necessary precautions [37]. Another study has reported that even farmers who can read the manufacturers' instructions are sometimes unable to translate this awareness into their practices [17] and this is not different from farmers within the Bosomtwe basin.

\subsubsection{Farmers' Perception of Pesticide and Fertilizer Use}

To find the extent of farmers' perception of pesticides and fertilizers use, it was divulged that $83 \%$ of the farmers within the Bosomtwe basin used pesticide and fertilizer in securing good crops while $13 \%$ did not use pesticides or fertilizer at all. The perception of the use of pesticides in the Bosomtwe basin was not different from the perception of most farmers in developing countries [15]. Farmers within the Bosomtwe basin see agrochemicals (pesticide and fertilizer) as a common element of agricultural technology and are commonly utilized throughout production seasons for controlling diseases, pests and weeds [38]. Farmers enumerated reasons for using agrochemicals which were in line with the claims of [39] which include economic benefits such as yield and quality of crops, decrease of other inputs like labor and fuel, etc.

\section{Conclusion and Recommendation}

The findings from the survey and laboratory results showed appreciable levels of pesticides and nutrients in the lake water. Most of the organochlorine pesticides detected in the lake water were not actively used in the basin anymore but their concentration still persists. The mean concentration of diazinon $(0.28 \pm 0.03$ $\mathrm{ppb}$ ) was higher than the WHO $0.05 \mathrm{ppb}$ and USEPA $0.04 \mathrm{ppb}$ for surface water bodies. The detection of diazinon confirms the findings from the field survey, which revealed that diazinon, is an active ingredient of a pesticide with a trade name "Akate suro", which is extensively used by cocoa farmers along the banks 
of the lake. The level of nitrate in the lake was far below the W.H.O limit of 10 $\mathrm{mg} / \mathrm{L}$. The mean concentration of phosphate in the lake water had marginally increased when compared with the mean values of $0.40 \mathrm{mg} / \mathrm{L}$ recorded by [13] in the same lake. The low level of education of the people in the Bosomtwe basin could also be an indicator of poor or misapplication of agrochemicals on farms which lead to nutrients and pesticides residue in the lake water. Farmers enumerated reasons for using agrochemicals which include economic benefits such as yield and quality of crops, decrease of other inputs like labor and fuel. It is highly recommended that farmers within the basin practice zero-tillage agriculture in order to reduce the movement of soil sediments and the constituent thereof (pesticides and nutrients) into the lake water. The Ministry of Food and Agriculture (MOFA) through their extension services gives periodic training and workshops to farmers within the Bosomtwe Basin on good use and correct application of agrochemicals.

\section{Acknowledgements}

The authors of this work wish to express their profound gratitude to the people living around the lake for their co-operation during sampling and personal interview for the study. The authors are also grateful to Isaac Owusu Bobie, Hayford Asante Asiedu and Portia Ampomah for assisting in data collection.

\section{Conflicts of Interest}

The authors declare no conflicts of interest regarding the publication of this paper.

\section{References}

[1] ILEC (International Lake Environment Committee Foundation) (2007) Integrated Lake Basin Management: An Introduction. International Lake Environment Committee Foundation, Kusatsu.

[2] Adu-Boahen, K., Emmanuel, M.A., Kwaku, K.K. and Osman, A. (2014) SocioEconomic Impact of Lake Bosomtwe Shoreline Changes on Catchment Residents in Ghana. International Journal of Scientific and Research Publications, 674, 1-7.

[3] Oerke, E.C. and Dehne, H.W. (2004) Safeguarding Production Losses in Major Crops and the Role of Crop Protection. Crop Protection, 23, 275-285. https://doi.org/10.1016/j.cropro.2003.10.001

[4] Cooper, J. and Dobson, H. (2007) The Benefits of Pesticides to Mankind and the Environment. Crop Protection, 26, 1337-1348.

https://doi.org/10.1016/j.cropro.2007.03.022

[5] Bürger, J., de Mol, F. and Gerowitt, B. (2008) The "Necessary Extent" of Pesticide Use. Thoughts about a Key Term in German Pesticide Policy. Crop Protection, 27, 343-351. https://doi.org/10.1016/j.cropro.2007.06.006

[6] Essumang, D.K., Togoh, G.K. and Chokky, L. (2009) Pesticide Residues in the Water and Fish (Lagoon tilapia) Samples from Lagoons in Ghana. Bulletin of the Chemical Society of Ethiopia, 23, 19-27. https://doi.org/10.4314/bcse.v23i1.21294

[7] McDowell, R.W. and Hamilton, D.P. (2013) Nutrients and Eutrophication: Intro- 
duction. Marine and Freshwater Research, 64, iii-vi. https://doi.org/10.1071/MF13059

[8] Mariyono, J. (2008) Direct and Indirect Impacts of Integrated Pest Management on Pesticide Use: A Case of Rice Agriculture in Java, Indonesia. Pest Management Science, 64, 1069-1073. https://doi.org/10.1002/ps.1602

[9] Abreu, A.D, Salinas, A.H. and Clusener-Godt, M. (2016) Sustainable Management of the Lake Bosomtwe in the Ashanti Region of Ghana. United Nations Educational, Scientific and Cultural Organization (UNESCO), Place de Fontenoy, Paris.

[10] American Public Health Association (APHA) (1998) Standard Methods for the Examination of Water and Wastewater. 20th Edition, American Public Health Association, Washington DC.

[11] Afful, S., Awudza, J.A.M., Osae, S. and Twumasi, S.K. (2013) Assessment of Synthetic Pyrethroids Residues in the Waters and Sediments from the Weija Lake in Ghana. European Chemical Bulletin, 2, 183-187.

[12] Frimpong, K.S., Yeboah, P., Fletcher, J.J., Adomako, D., Osei-fosu, P. and Acheampong, K. (2012) Organochlorine Pesticides Levels in Fermented Dried Cocoa Beans Produced in Ghana. Elixir Agriculture, 44, 7280-7284.

[13] Wireko, A. (2015) Impacts of Land Use/Cover Change on Water Quality in Lake Bosomtwe Basin of Ghana. Doctoral Dissertation, University of Ghana, Accra.

[14] Varó, I., Navarro, J.C., Amat, F. and Guilhermino, L. (2003) Effect of Dichlorvos on Cholinesterase Activity of the European Sea Bass (Dicentrarchus labrax). Pesticide Biochemistry and Physiology, 75, 61-72. https://doi.org/10.1016/S0048-3575(03)00019-1

[15] Hasan, S.S., Ghosh, M.K., Arefin, M.S. and Sultana, S. (2016) Farmers' Attitude towards Using Agro-Chemicals in Rice Production: A Case in Laxmipur District of Bangladesh. The Agriculturists, 13, 105-112. https://doi.org/10.3329/agric.v13i2.26599

[16] Okoffo, E.D. (2015) Pesticide Use and Pesticide Residues in the Drinking Water, Soil and Cocoa Beans in the Dormaa West District of Ghana. Unpublished MPhil. Thesis, University of Ghana, Accra.

[17] Isin, S. and Yildirim, I. (2007) Fruit-Growers' Perceptions on the Harmful Effects of Pesticides and Their Reflection on Practices: The Case of Kemalpasa, Turkey. Crop Protection, 26, 917-922. https://doi.org/10.1016/j.cropro.2006.08.006

[18] Ajayi, O.C. and Akinnifesi, F.K. (2007) Farmers Understanding of Pesticide Safety Labels and Field Spraying Practices: A Case Study of Cotton Farmers in Northern Cte dIvoire. Scientific Research and Essays, 2, 204-210.

[19] Abowei, J.F.N., Davies O.A. and Eli, A. (2010) Physico-Chemistry, Morphology and Abundance of Fin Fish of Nkoro River, Niger Delta, Nigeria. International Journal of Pharmaceutical and Bio-Physiology, 1, 1-13.

[20] Rauh, V.A., Garcia, W.E., Whyatt, R.M., Horton, M.K., Barr, D.B. and Louis, E.D. (2015) Prenatal Exposure to the Organophosphate Pesticide Chlorpyrifos and Childhood Tremor. Neurotoxicology, 51, 80-86.

https://doi.org/10.1016/j.neuro.2015.09.004

[21] Quintana, P.J., Delfino, R.J., Korrick, S., Ziogas, A., Kutz, F.W., Jones, E.L. and Garshick, E. (2004) Adipose Tissue Levels of Organochlorine Pesticides and Polychlorinated Biphenyls and Risk of Non-Hodgkin's Lymphoma. Environmental Health Perspectives, 112, 854-861. https://doi.org/10.1289/ehp.6726

[22] Clottey, M.N.K., Asmah, R., Ofori-Danson, P.K., Ameworwor, M.Y. and Karikari, 
A.Y. (2016) Impacts of Cage Culture on Physico-Chemical and Bacteriological Water Quality in Lake Volta, Ghana. African Journal of Aquatic Science, 41, 473-480. https://doi.org/10.2989/16085914.2016.1255587

[23] Agwa, A., Leheta, H., Salem, A. and Sadiq, R. (2013) Fate of Drilling Waste Discharges and Ecological Risk Assessment in the Egyptian Red Sea: An Aquivalence-Based Fuzzy Analysis. Stochastic Environmental Research and Risk Assessment, 27, 169-181. https://doi.org/10.1007/s00477-012-0574-0

[24] Maghanga, J.K., Kituyi, J.L., Kisinyo, P.O. and Ng'etich, W.K. (2013) Impact of Nitrogen Fertilizer Applications on surface Water Nitrate Levels within a Kenyan Tea Plantation. Journal of Chemistry, 2013, Article ID: 196516. https://doi.org/10.1155/2013/196516

[25] Hecnar, S.J. (1995) Acute and Chronic Toxicity of Ammonium Nitrate Fertilizer to Amphibians from Southern Ontario. Environmental Toxicology and Chemistry, 14, 2131-2137. https://doi.org/10.1002/etc.5620141217

http://creativecommons.org/licenses/by-sa

[26] Turner, B.F., Gardner, L.R. and Sharp, W.E. (1996) The Hydrology of Lake Bosomtwe a Climate-Sensitive Lake in Ghana, West Africa. Journal of Hydrology, 183, 243-261. https://doi.org/10.1016/0022-1694(95)02982-6

[27] Muller, D.K. and Helsel, D.R. (1999) Nutrients in the Nation's Water-Too Much of Good Thing? Circular 1136. US Geological Survey, Denver.

[28] Karikari, A.Y. and Ansa-Asare, O.D. (2006) Physico-Chemical and Microbial Water Quality Assessment of Densu River of Ghana. West African Journal of Applied Ecology, 10, 1-12. https://doi.org/10.4314/wajae.v10i1.45701

[29] Bukola, D., Zaid, A., Olalekan, E.I. and Falilu, A. (2015) Consequences of Anthropogenic Activities on Fish and the Aquatic Environment. Poultry, Fisheries \& Wildlife Sciences, 3, Article No. 138. https://doi.org/10.4172/2375-446X.1000138

[30] Boyd, C.E. (1979) Water Quality in Warm Water Fish Ponds. Auburn University, Agricultural Experiment Station, Auburn.

[31] Bouwer, H. (2002) Integrated Water Management for the 21st Century: Problems and Solutions. Journal of Irrigation and Drainage Engineering, 128, 193-202. https://doi.org/10.1061/(ASCE)0733-9437(2002)128:4(193)

[32] Malik, S.J. (1998) Rural Poverty and Land Degradation: What Does the Available Literature Suggest for Priority Setting for the Consultative Group on International Agricultural Research: A Report. Consultative Group on International Agricultural Research (CGIAR), Washington DC.

[33] Scherr, S.J. (2000) A Downward Spiral? Research Evidence on the Relationship between Poverty and Natural Resource Degradation. Food Policy, 25, 479-498. https://doi.org/10.1016/S0306-9192(00)00022-1

[34] Wunder, S. (2001) Poverty Alleviation and Tropical Forests-What Scope for Synergies? World Development, 29, 1817-1833. https://doi.org/10.1016/S0305-750X(01)00070-5

[35] Leonard, S.D. and Wogalter, M.S. (2000) What You Don't Know Can Hurt You: Household Products and Events. Accident Analysis \& Prevention, 32, 383-388. https://doi.org/10.1016/S0001-4575(99)00072-X

[36] Banda, S.F. and Sichilongo, K. (2006) Analysis of the Level of Comprehension of Chemical Hazard Labels: A Case for Zambia. Science of the Total Environment, 363, 22-27. https://doi.org/10.1016/j.scitotenv.2005.10.011

[37] Damalas, C.A., Theodorou, M.G. and Georgiou, E.B. (2006) Attitudes towards Pes- 
ticide Labeling among Greek Tobacco Farmers. International Journal of Pest Management, 52, 269-274. https://doi.org/10.1080/09670870600792101

[38] Damalas, C.A. and Eleftherohorinos, I.G. (2011) Pesticide Exposure, Safety Issues, and Risk Assessment Indicators. International Journal of Environmental Research and Public Health, 8, 1402-1419. https://doi.org/10.3390/ijerph8051402

[39] Damalas, C.A. (2009) Understanding Benefits and Risks of Pesticide Use. Scientific Research and Essays, 4, 945-949. 